\title{
Notes on the identity and distribution of the endemic Leucas nepetifolia (Lamiaceae: Lamioideae) in southern India
}

\author{
K.P. Vimal and P. Sunojkumar* \\ Department of Botany, University of Calicut, Calicut University P.O., Malappuram, Kerala - 673635, India. \\ *E-mail: drsunoj@gmail.com
}

\begin{abstract}
Leucas nepetifolia Wall. ex Benth. (Lamiaceae: Lamioideae), a species endemic to southern India, hitherto recorded only from Deccan region in Andhra Pradesh is reported here from Western Ghats in Tamil Nadu after several years. Remarks about its distribution in regional Floras based on wrong identification are clarified. Detailed description and photographs are provided for easy identification.
\end{abstract}

Keywords: Leucas nepetifolia, Tamil Nadu, Western Ghats

\section{Introduction}

The genus Leucas R. Br. comprises of c. 100 species found occurring on dry or disturbed ground in tropical to southern Africa, Arabian Peninsula, Iran to South China, Taiwan, Japan and Southeast Asia (Harley et al., 2004).

Leucas s.s. is an Asian genus with 41 species, of which 40 are found in India (Sunojkumar, 2005a). Southern India shows a highest diversity of 32 species including 14 endemics (Sunojkumar, 2005b). In the last decade, two species having restricted distribution were described from southern Western Ghats (Sunojkumar, 2005a, 2008).

Leucas nepetifolia is a south Indian endemic species described by Bentham based on collection mentioned in Wallich's Numerical list. No precise locality was mentioned by Bentham in any of his works (1830, 1832, 1848). Hooker (1885) quoted Rottler's manuscript and mentioned locality as Pullejmadam "in a journey to Hyderabad" which indicates its locality in Deccan region in Telangana state. Gamble (1924) mentioned "Deccan, Hyderabad Journey (Heyne); Guntur District, at Bellamkonda (Cleghorn)" areas in Andhra Pradesh as the place of collection. All these records indicate that this species is confined only to Deccan region in Andhra Pradesh. Singh (2001) mentioned its distribution in Tamil Nadu but no supporting specimens were cited in the work. Moreover, no specimen from Tamil Nadu could be seen in any Indian herbaria to support this citation.
A comprehensive revision of this genus was initiated by the second author in 1998 and he had examined all relevant Floras and representative specimens in major Indian and a few European herbaria. This species was reported in 'Synoptic Flora of Mysore District' (Rao \& Razi, 1981) and 'Flora of Sri Venkateswara National Park' (Benjamin \& Murthy, 2013). But, these two were based on wrong identification of L. montana as revealed from the examination of voucher specimens housed at $\mathrm{MH}$. Further, no recent collection of this species could be found in other Indian herbaria (BSI, CAL, CALI, KFRI, MH, RHT, SKU, SUK, TBGT). With the available information, it is confirmed that the species is restricted to Deccan region and no collection is made in recent years.

As part of a project to investigate molecular biogeography of the genus Leucas, the authors collected specimens from all over India. A few populations noticed at Maruthwamala in Kanyakumari district of Tamil Nadu were identified as L. nepetifolia. Growth of plants was observed for two years in the field and confirmed its natural occurrence. Detailed morphological and molecular studies were carried out to confirm its identity. The present collections, thus form a new distributional record of this species from the southern tip of Western Ghats and recollection of this species after many years. A detailed description and photographs for easy identification of this taxon. Young plants of this species is grown in Calicut University Botanic Garden for conserving the same. 


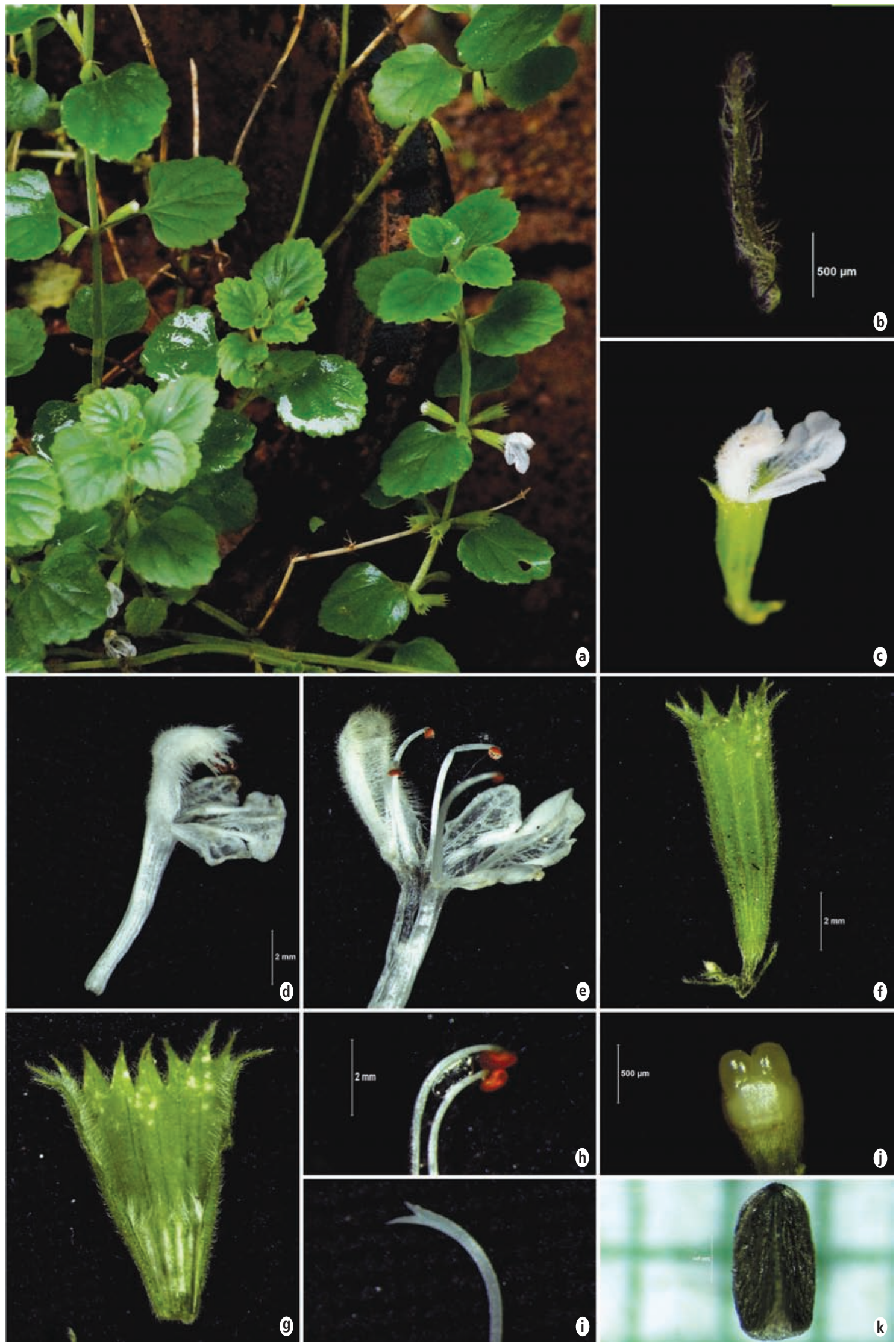

Fig. 1. Leucas nepetifolia Wall. ex Benth.: a. Habit; b. Bracteole; c. Flower; d. Corolla; e. Corolla with stamens split-open; f. Calyx; g. Calyx split-open; h. Stamens; i. Stigma; j. Ovary on disk; k. Mature nutlet. 
Leucas nepetifolia Wall. [Numer. List No. 2526] ex Benth. in Wall., Pl. Asiat. Rar. 1: 62. 1830; Labiat. Gen. Spec. 3 (Fasc. 6): 609. 1834 \& in DC., Prodr. 12: 527. 1848; Hook.f., Fl. Brit. India 4: 681. 1885; Gamble, Fl. Madras: 1150. 1924; Mukerjee, Rec. Bot. Surv. India 14(1): 177. 1940; Pull. \& Moulali, Fl. Andhra Pradesh 2: 774. 1997; V. Singh, Monogr. Ind. Leucas: 125. 2001 (p.p. excl. spec. A.S. Rao 80202).

Fig. 1

Annual, spreading, 30-40 cm high, profusely branched; branches terete to obtusely quadrangular, densely pubescent with soft retrorse hairs all over; internodes 2-4 cm long. Leaves (sub)orbicular to deltoid, $1.5-2.5 \times 1.4-2.4 \mathrm{~cm}$, almost truncate to rounded at base, crenate with 6 or 7 broad teeth at margins, obtuse at apex, pubescent above, tomentose with soft retrorse hairs beneath, more so on veins; midvein prominent beneath; lateral veins 2 or 3 per side; petioles $5-13 \mathrm{~mm}$ long, densely pubescent. Inflorescence in lax axillary clusters; flowers 3-6 per verticil, $1.4-1.5 \mathrm{~cm}$ long; pedicels 1-1.5 mm long, pubescent; bracteoles $1.8-2.8 \times$ $0.2-0.4 \mathrm{~mm}$, persistent, setaceous, clothed with dense soft hairs. Calyx tubular-campanulate, 9-10 $\mathrm{mm}$ long, base narrowed to pedicel, longitudinally 10-ribbed, hispid outside, inside hairy at upper onethird portion and a ring of long silky hairs projecting towards corolla at middle of lower portion; teeth 10 , almost equal, 1.5-2 mm long, straight, triangular, tip pointed, hispid outside. Corolla 11-12 mm long, white; tube 7-7.5 mm long, forwardly slightly bend and fully included in calyx, inside annulate at middle with a ring of fleshy hair fringes; lower lip 6-7 × 5-6 mm; median lobe 2-2.5 × 3.5-4 mm, front side slightly emarginate at middle; side lobes to $5 \times 2 \mathrm{~mm}$; upper lip 5-6 $\mathrm{mm}$ long, concave, outside fully hairy with soft white antrorse hairs, margin ciliate. Staminal filaments glabrous, middle pair short; anther lobes orange-red, slightly project outside corolla tip, theca confluent. Style 10-11 $\mathrm{mm}$ long, slightly bend towards upper half; stigma unequally bilobed; upper lobe c. $0.25 \mathrm{~mm}$ long, lower $0.4-0.5 \mathrm{~mm}$ long; basal disk cup-shaped with almost equal lobes. Nutlets oblongoid, triangular from middle downwards, $1.7-1.85 \times 0.75-0.9 \mathrm{~mm}$, attached at pointed base, rounded at apex, irregular surface with longitudinal striations, dark greyish to blackish.

Flowering \& Fruiting: September-December.

Habitat: Grows on lateritic rock surfaces and crevices at c. 50 m elevation.

Specimens examined: INDIA, Andhra Pradesh, Cuddapah district, Sidhout, S.K. Wagh 5883 (BLAT); Nellore district, Udayagiri, S.K. Wagh
6704 (BLAT). Tamil Nadu, Kanyakumari district, Maruthwamala, 20.11.2016, K.P. Vimal, K. Shinoj \& P. Sunojkumar CU151007 (CALI).

Distribution: India (Andhra Pradesh, Tamil Nadu and Telangana).

\section{Acknowledgements}

The authors thank the Curators and Directors of B, BM, BSI, C, CAL, CALI, CGE, K, KFRI, MH, P, RHT, SKU and TBGT, for permission to study the specimens, Dr. J.H.F. Benjamin, Scientist, Botanical Survey of India, Southern Regional Centre, Coimbatore, for sending photographs of specimens, and Kerala Forest Department, for permission to collect specimens. They also acknowledge the financial support provided by the Department of Biotechnology, Government of India (Grant No. BT/PR5423/BCE/8/907/2012; dated $19 / 06 / 2013$ ) to study the phylogeny and biogeography of the genus Leucas.

\section{Literature Cited}

Benjamin, J.H.F. \& G.V.S. Murthy 2013. Flora of Sri Venkateswara National Park, Andhra Pradesh. Botanical Survey of India, Kolkatta.

Bentham, G. 1830. Leucas. In: Wallich, N. (ed.), Plantae Asiaticae Rariores. Vol. 1. Treuttel \& Würtz, London. pp. 60-62.

Bentham, G. 1832. Labiatarum Genera et Species. James Ridgway \& Sons, London. pp. 1-783.

Bentham, G. 1848. Labiatae. In: Candolle, A.P. de (ed.), Prodromous Systematis Naturalis Regni Vegetabilis. Treuttel \& Würtz, Paris. pp. 27-603.

Gamble, J.S. 1924. Flora of the Presidency of Madras. Adlard \& Son Ltd., London. pp. 1106-1159.

Harley, R.M., Atkins, S., Budantsev, A.L., Cantino, P.D., Conn, B.J., Greyer, R., Harley, M.M., De Kok, R., Krestovskaja, T., Morales, R., Paton, A.J., Ryding, O. \& T. Upson 2004. Labiatae. In: Kubitzki, K. \& J.W. Kadereit (eds.), Families and genera of flowering plants. Vol. 7. Springer, Berlin. pp. 167-275.

Hooker, J.D. 1885. The Flora of British India. Vol. 4. L. Reeve \& Co., London. pp. 604-705.

Rao, R.R. \& B.A. Razi 1981. A synoptic Flora of Mysore District. Today \& Tomorrow Publishers, New Delhi. pp. 511-512.

Ryding, O. 1998. Phylogeny of the Leucas group (Lamiaceae). Syst. Bot. 23: 235-247. 
Scheen, A.C. \& V.A. Albert 2007. Nomenclatural and taxonomic changes within the Leucas clade (Lamioideae; Lamiaceae). Syst. \& Geogr. Pl. 77: 229-238.

Scheen, A.C. \& V.A. Albert 2009. Molecular phylogenetics of the Leucas group (Lamioideae; Lamiaceae). Syst. Bot. 34(1): 173-181.

Sebald, O. 1980. Die Gattung Leucas R. Br. (Labiatae) in Afrika und auf der arabischen Halbinsel. Stuttgarter Beitr. Naturk. 341: 1-200.

Singh, V. 2001. Monograph on Indian Leucas R. Br. (Dronapushpi) Lamiaceae. Scientific Publishers, Jodhpur.
Sunojkumar, P. 2005a. Leucas sebaldiana Sunojk. (Lamiaceae), a new species from India. Candollea 60(1): 233-236.

Sunojkumar, P. 2005b. Morphologic and taxonomic studies on the genus Leucas R. Br. (Lamiaceae) in southern peninsular India. Ph.D. Thesis, University of Calicut, Kerala (unpublished).

Sunojkumar, P. 2008a. Leucas sivadasaniana, a new species of Lamiaceae (Leucas sect. Astrodon) from peninsular India. Novon 18: 247-250.

Received: 3.4.2017

Revised and Accepted: 12.6.2017 